\title{
AN ELECTRON MICROSCOPIC STUDY OF THE COCHLEAS OF AN INDIVIDUAL WITH BILATERAL MENIERE'S DISEASE
}

\author{
Robert S. Kimura (Harverd Univ. U.S.A.) \\ 高橋 忠彦 (東京都)
}

Harold F. Schuknecht (Harvard Univ. U.S.A.)

Many light microscopic investigations have been performed on the temporal bones of patients having Meniere's disease. In this paper, we are reporting for the first time an electron microscopic study on the organ of Corti of an individual who had bilateral Meniere's disease; the left side affected for 34 years and the right side for 7 years. Audiograms were made on three occasions, the final one about three months prior to death from acute myocardial infarction at the age of 59. The final audiogram showed the left ear to have a hearing loss of $80 \mathrm{DB}$ and the right a loss of $50 \mathrm{DB}$ in the range of 0.5 to $2 \mathrm{Kc}$. Both ears showed greater threshold elevations for the higher frequencies. The discrimination scores were $0 \%$ in the left ear and $74 \%$ in the right. About $11 / 2$ hours after death, both ear were fixed with osmium and the specimens were processed in the routine manner for elcetron microscopy. Sections were localized on the cochlear spiral graphs and were examined throughout the cochlea.

\section{Left Ear:}

The hair cell population appeard near normal in the second and apical turns, but was decreased in the basal turn. Many of the outer hair cells showed degenerative changes. Among the changes were giant stereocilia, a cuticular-like substance intermixed with a dense substance below the nucleus, decrease in subsurface and subsynaptic cisternae, and atrophic nuclei. The random occurrence of degenerative changes in the nuclei of the hair cells favors an antemortem rather than a postmortem etiology. The nerve endings appered reduced in number even in association with normal-appearing hair cells. The inner hair cells showed less change than the outer hair cells. Some of the inner hair cells had lost some of their stereocilia, but no abnormalities could be detected within the cytoplasm. The number of nerve endings appeared decreased in some areas. The nerve fiber population of the inner and outer spiral bundles and tunnel spiral bundle appeared normal in the apical region but decreased in the basal region. At the basal end where both the inner and outer hair cells were totally absent, some nerve fibers were still discernible between the supporting cells. A large number of unmyelinated fibers were found passing in a spiral direction at the tympanic lip of the limbus spiralis. These are assumed to be efferent fibers. No synapses were found among them, though desmosomes were identified. Cursory study of the spiral ganglia in the apical region revealed both myelinated and unmyelintaed types showing no viral particles or other changes.

The stria vascularis of the bassal turn was severely atrophied, with some unusual thickening at the margins of the atrophic region. Lesser degrees of atrophy were seen in the middle and apical turns. Grossly, the degenerative changes consisted of flattening of merginal cells, loss of intermediate cells, and decrease in the number of capillaries. The basal cells 
were relatively unaffected. The atrophy was most common near the spiral prominence and Reissner's membrane.

Reissner's membrane was greatly distended throughout the cochlea. At the apical end, it herniated into the helicotrema and extended into the scala tympani, where it was found lying against the basilar membrane. Its epithelial cells were flattened with loss of microvilli, the cytoplasm was very electron dense, and the basal surface had become smooth. There were often numerous wide gaps between the mesothelial cells.

The tectorial membrane and the basilar membrane appeared normal. All supporting cells showed numerous lipoid masses and lipofuscin granules at their apices. Except for some thickening of the basement membrane, the blood vessels appeaed normal. Nerve fibers were only found adjacent to the vessels located at the tympanic lip of the limbus.

\section{Right Ear;}

The right cochlea showed fewer atrophic changes than the left. The hair cell population was decreased at the basal end, but appeared near normal in other areas. Both normal and abnormal outer hair cells were present. The changes were almost identical to those described for the left cochlea. Some cells were displaced, sinking deeply among the Deiters' cells. Some nuclei were located below the level of their nerve ending areas. The empty spaces left by degenerating nerve endings were filled by finger-like extensions of Deitens' cells. Most of the inner hair cells were present. Some had giant stereocilia. Only occasional nerve endings and fibers showed atrophic changes. The population of the inner and outer spiral bundles and tunnel spiral bundle was decreased only at the basal end. The unmyelinated spiral fibers at the tympanic lip were numerous; some of them contained vesicles, sometimes with dense cores.

The stria vacularis showed some atrophy, but much less than the left cochlea. Small oval particles with double membranes around dense homogeneous substances were seen in some marginal cells. The light-appearing basal cells contained numerous small granules, which are presumed to be glycogen granules. A large vessel was seen occupying almost the entire epithelial thickness of the stria; the adjacent marginal cells were atrophic.

Reissner's membrane showed slight distension in the basal $5 \mathrm{~mm}$ and severe distension elsewhere. In the less distended areas, it showed a thick layer of homogeneous or filamentous substance between the endolymphatic epithelium and mesothelial cells. The epithelial cells were flat in some areas, while in other areas the basal surface became irregular and projected deeply into the the homogeneous layer. The mesothelial cell layer was continuous. Reissner's membrane became thinner as the hydrops became more severe, and wide gaps began to appear between the mesothelial cells. There was a large mass appearing to be a microorganism lying on the mesothelial cells in the basal turn. It consisted of a homogeneous substance mixed with chromatin-like aggregates and was encapsulated by a thick dense membrane.

The Deiters' cells contained small particles different from those seen in Reissner's membrane. These particles consisted of a dense substane surrounded by a double membrane. The Deiters' cells sent cell processes into the areas adjacent to the outer hair cells particularly in the apical region. All supporting cells appeared normal. The spiral ligament showed normal fibrocytes without evidence of viral particles.

The foregoing observations do not resolve the etiology of Meniere's disease. The discovery of a single microorganism is of doubtful significance. The particles found in the stria vascularis and Deiters' cells are probably lysosomes or some previously unknown secretory granules. There were no unusual cells anywhere in the membranous wall of the cochlear duct. The blood vessels showed no significant changes. No unmyelinated fibers were observed in association with the blood vessels of the stria vascularis or spiral ligament. The nerve fibers seen in the area adjacent to the vessels at the tympanic lip probably represent the normal distribution of cholinergic fibers and are presumed to be unrelated to the cause of this disease. 
The magnitude of the hearing losses in these ears seems too great to be solely accounted for by the modest atrophic changes in the hair cells. A more detailed population count of the hair cells and nerve endings is in progress and may be revealing. At this time we doubt that the changes are sufficient to account for the hearing losses.

Atrophy of the stria vascularis has been shown to be a common cause for deafness of aging. In the present study, strial atrophy was found in both ears, the left more than the right. However, the spatial distribution and severity seems to be inadequate to account for the hearing losses, particularly in the right ear. The thick hyperplastic strial epithelium seen in the left ear may be a compensatory activity for the loss of adjacent atrophic stria.

The only positive correlaticn between morpholo- gical alteration and function is the distension of Reissner's membrane. Possibly this membrane, 'if extend beyond a certain limit, undergoes a loss of some function, such as permeability or sound conduction. One observation is clear, the ear with the more severe hydrops and the greater atrophic change in the sensory and neural structure.

These findings raise the possibility that the hearing loss may be contributed to by biochemical alterations in endolymph or perilymph or cytochemical alterations in the hair cellr and/or nervous tissue. The observations are compatible with the thesis that the cochlear changes are secondary to volumetric and qualitative changes in endolymph, similar to those occurring in experimental endolymphatic hydrops following surgical obstruction of the endolymphatic duct.

\section{蝸牛内直流電位の消長とマイクロフォン電位との相関性}

\section{志多亭 (大阪鉄道病院)}

有毛細胞起源である Cochlear Microphonics (以下 CM) 汢 Summating Potential (以下SP) とともに現段 階では一応聴覚末梢感覚装置の受容電位であると考えら れ，内耳におけるエネルギ一変換を示寸電気的表現とし て理解されている。この上うな有毛細胞の電気的な activity を決定的に支えているのは Reticular Lager を境と して Endocochlear DC Poteutial (以下 EP) とコルチ 器内負電位とによつて構成される $180 \mathrm{mV} に$ によぶ直流 電位勾配であり，この直流電位差の減少は有毛細胞自体 に障害がなくても即 $\mathrm{CM}$ の減少となつて現われる。し かもこの直流電位差を構成する両電位の中聴器毒中毒時 等の特殊な場合を除いて各種の条件負荷に対してもコル 千器紐胞内負電位は抵抗性が強く，その值が安定であ り，この電位差の值を変動させる主因はほとんどの場合 EP の側にある。したがって EP の変動はそのまま直流 電位勾配の変動として $\mathrm{CM}$ にこれと一致した変動を強 制することになる訳であるが，モルモットを実験動物と した場合，ある条件下では EP と CM が必ずしも一致 した変動を示さぬ事実が発見された。この不一致の根源
を検索することは EP の発生起源の追究に連なると同 時に CM 発生にあたつての有毛細胞の直流電位勾配利 用能の背景を知るための手段ともなる。この意味でまず 螖牛中央階の Polarization 種々のレベルに変換して, これに伴なら $\mathrm{CM}$ の変化を検討した。このために尖端 $1 \sim 2 \mu$ の硝子毛細管電極を 2 本, 螖牛基礎回転中央階に 挿入し， 1 本は誘導電極とし, 他の 1 本は別に鼓室階に 扱入した同様の毛細管電極ととむに通電電極とした．電 流そのものによる有毛細胞障害を避けるために通電電極 間には更に 3 5M $\Omega$ の抵抗を入れて通電電流は最大で も $15 \mu \mathrm{A}$ をこえないように留意した，正常状態で EPが $80 \mathrm{mV}$ あることを確認した上で通電により $\mathrm{EP}$ を増减 し， EP とCM との相関性を観察した場合， EP の減少 すなわち中央階の電圧低下時には $\mathrm{CM}$ はこれと一致す る減少を示すが，EP の増大すなわち中央階の電圧上昇 時には $\mathrm{CM}$ は必ずしもこれと一致した増大を示さない ことが分つた，すなわち EP が 90〜110mV に達する までは $\mathrm{CM}$ はこの中央階電圧増大分に応じた增大を 示すが，次第にその増大度は小となり， $\mathrm{EP} か ゙$ 120 130 